\title{
The epidemiology and chemotherapeutic approaches to the control of urinary schistosomiasis in school-age children (SAC): a systematic review
}

\author{
Tolulope Ebenezer Atalabi ${ }^{1^{*}}$ (1) and Taiwo Oluwakemi Adubi
}

\begin{abstract}
Background: Human schistosomiases are acute and chronic infectious diserses f poverty. Currently, epidemiological data of urinary schistosomiasis (US) in school-age children together making it difficult to ascertain the true status of the disease. Based o, his premise, we set out to carry out this review.

Method: To achieve this aim, we carried out a computer-aided search of Puomed, Web of Science, Science Direct, African Journals OnLine (AJOL) and the database of World Health Organ zation. However, the information obtained from these sources was supplemented with additional lite aturo rom Mendeley, Research Gate, and Google.

Results: The search yielded 183 literatures of which 93 fuli vt re earch, review and online articles were deemed fit for inclusion. Our key findings showed that: (1) of w World $\mathrm{H}_{\mathrm{c}}$.h Organization (WHO) Regions, Africa is the most endemic zone for US, with Kenya and Senegal reco (2) SAC within the range of 5-16years contri ute mo, ighificantly to the transmission cycle of US globally; (3) gender is a factor to watch out for, with $\mathrm{p}$ alt ten recording the highest prevalence and intensity of infection; (4) contact with open, potentially infested water waces contribute significantly to transmission; (5) parental factors (occupation and education status) $\mathrm{p}$ edispose SAC to US; (6) economic vis a vis ecological factors play a key role in infection transmission; and (7) in the st decadde, a treatment coverage of $45 \%$ was never achieved globally for SAC or non-SAC treatment categorv for un. ochistosomiasis.
\end{abstract}

Conclusion: In view of the WH a plan to eliminate schistosomiasis by 2020 and the findings from this review, it is obvious that+ programmes be scal d un margi, ally, particularly in the African region of WHO. While US-based researches should be sponsored at the s s-ruverevel to unveil hidden endemic foci, adequate facilities for Water, Sanitation, and Hygiene (WAS, should, put in place in all schools globally.

Keywords: Arevar e, Control, Urinary, Schistosomiasis, School, Children

* Correspondence: ebenezer2k2@gmail.com

${ }^{1}$ Department of Biological Sciences, Federal University, Dutsin-Ma, Km 65,

P.M.B. 5001, Dutsin-Ma, Katsina State, Nigeria

Full list of author information is available at the end of the article

(c) The Author(s). 2019 Open Access This article is distributed under the terms of the Creative Commons Attribution 4.0 International License (http://creativecommons.org/licenses/by/4.0/), which permits unrestricted use, distribution, and reproduction in any medium, provided you give appropriate credit to the original author(s) and the source, provide a link to the Creative Commons license, and indicate if changes were made. The Creative Commons Public Domain Dedication waiver (http://creativecommons.org/publicdomain/zero/1.0/) applies to the data made available in this article, unless otherwise stated. 


\section{Background}

Human schistosomiases are acute and chronic infectious diseases associated with abject poverty in 78 low and middle-income countries in the sub-tropical and tropical parts of the world where there is negligible access to potable water and adequate sanitation. The agents of etiology of these diseases are "blood-thirsty" digenetic trematodes in the genus Schistosoma $[1,2]$.

Freshwater gastropod snails in the genus Bulinus are suitable intermediate hosts to Schistosoma haematobium which causes urinary schistosomiasis. The transmission gap of the disease is bridged when people come into contact with unwholesome water sources [3-5] infested with the cercariae (infective larval form) which mechanically penetrates the skin of their human definitive hosts. A transmission cycle is consolidated when infected humans, due to lack of modern waste disposal facilities, indiscriminately pass urine-infested eggs in close proximity to water bodies where they hatch into larval form (called miracidia) which infect Bulinus. In humans, cercariae undergo series of larval migration before maturing into adults which migrate to the veins of the urinary tract where gravid females lay a large number of eggs which are responsible for the various signs, symptoms and morbidity associated with the disease. The classical sign of urinary schistosomiasis is haematuria, a term coined to describe the presence of blood in in Genital schistosomiais causes pathological damage n both sexes, with females being more at ris contracy ing Human Immuno-Deficiency Virus (H) [6,

Nonetheless, a review of the burder of schistoso, niasis has shown that over 200, 000 peopl die from the complications due to the disease in Sab ran Africa (SSA) annually while children ffer anaemia, stunted growth [8,9], urinary tract damas 10] and reduced mental ability to cop th academics. In advanced cases, hydronephros; 11 noteral and bladder fibrosis/ cancer commonly oscur 7 .

As a follow $a$ to the $\lrcorner 01$ World Health Assembly resolution WAA5. 9 , many endemic countries in Africa laun hed nationa, control programmes largely based on prev iv ch motherapeutic intervention with praziqu a ( D) targeting at least $75 \%$ of school-age iildr n-SAC (5-14 years old) and adults at risk of So tosomiasis $[12,13]$ by 2010 . This resolution aligns prop $y$ with earlier report that SAC, adolescent and young adults usually recorded the highest prevalence and intensities of schistosomiasis [14]. Meanwhile, the guideline of World Health Organization required that treatment of SAC (enrolled and not enrolled) be done: once every year for high-risk communities, once every two years for moderate-risk communities and twice during their Primary School Age in low-risk communities [13, 15].
Currently, epidemiological data on prevalence, intensity and control of US in SAC and adults are often reported together, thus making information peculiar to SAC to be insufficient in the literature. The implication of this is that it is difficult to ascertain the epidemiological status of the disease in this group to enhar e the success of control programmes targeting th group. Based on this premise, the aim of this review an was to study the epidemiology and chemotherapeutic egies to the control of US in SAC.

\section{Methods}

\section{Search strategy}

We carried out a computer dea ch of PubMed, Web of Science, Science Direct, rican Journals OnLine (AJOL) and the data as $f$ Worl/ Health Organization (WHO). However, the info ation obtained from these sources was s ppi hented/with additional literatures from Mendelo, ch Gate, and Google. The searches were per med independently by the authors using the words. "urinary/urinary schistosomiasis" in combination wh, "prevalence", "intensity", "morbidity", "control/praziquantel", "school" and "children".

\section{elec on criteria}

L r.tures that address prevalence, intensity, morbidity, inaicators or risk factors as well as the control of US, without restriction to year of publication, were included in this review article. Besides, such papers addressed school children specifically. The implication of this is that articles exclusively addressing intestinal schistosomiasis or other Neglected Tropical Diseases were not considered eligible for inclusion.

\section{Analysis and presentation of data}

The secondary data presented in this manuscript were manually extracted from the articles included in this review paper. Data imported into Microsoft Excel Spreadsheet were used to generate Bar Charts.

\section{Results}

\section{The search}

The search yielded 183 literatures. After proper scrutiny of the retrieved literatures, 93 full text research, review and online articles were deemed fit for inclusion. Consequently, this review is a product of the findings from these articles. The flow chart in Fig. 1 shows the result of our search.

\section{Characteristics of the included articles}

Of the 93 literatures included in this review, majority, 46 (49.46\%), were products of researches/reviews carried out in African WHO Region, with Nigeria recording the second largest number of articles, 19 (20.43\%). Switzerland in 


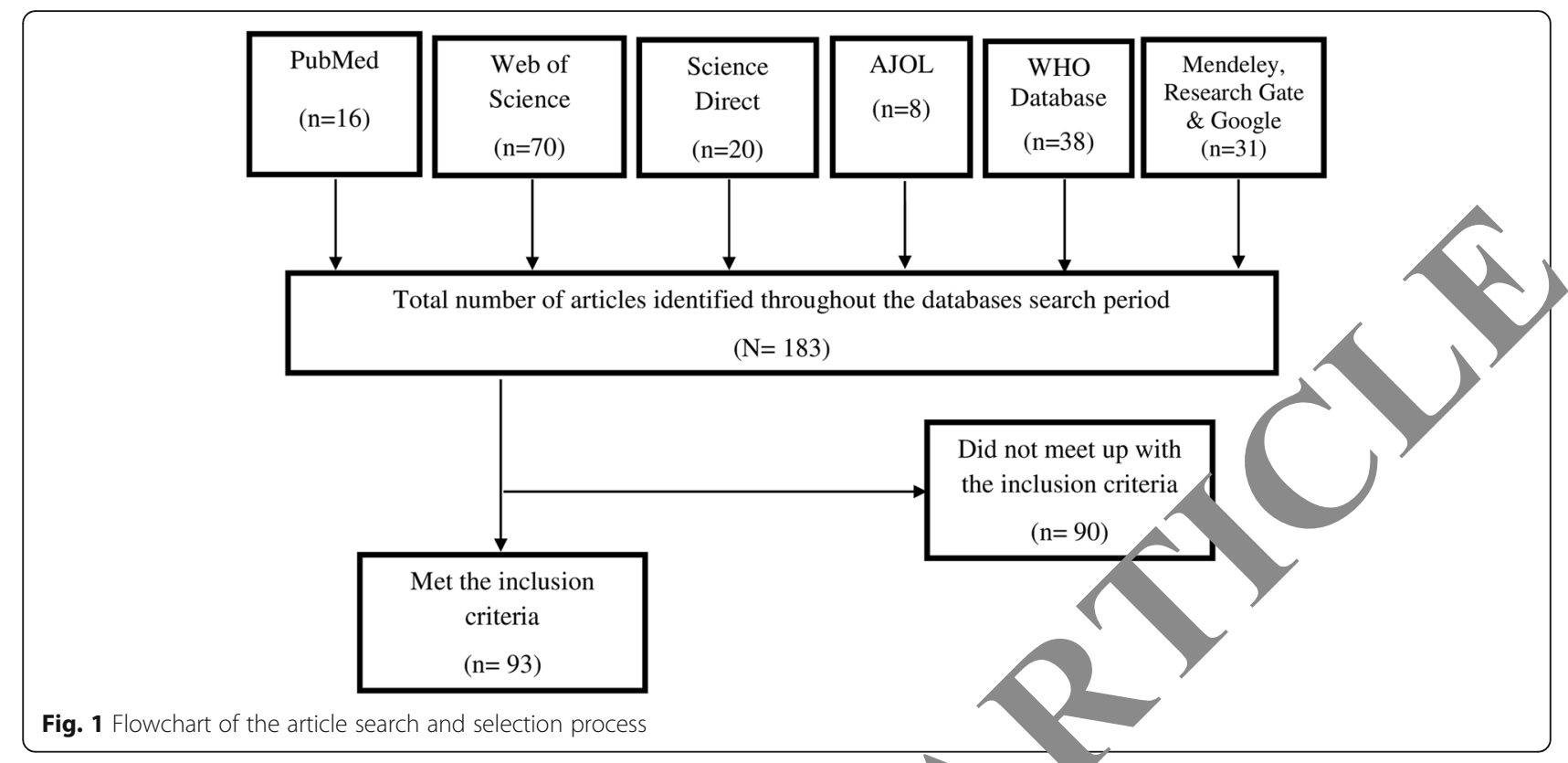

European Region, however, accounted for the largest, 22 (23.66\%), which were all technical reports/review articles (see Table 1).

The sampling years reported by the 61 research articles included in this review ranged from 1984 to 2017 , with the studies executed between 2004 and 2017 11 times more in number than those carried gat in of 1984-1993 and 1994-2003. Sixty-s poin Fifty-Eight percent (40), 63.93\% (39), and 60.66, 37) of the studies were cross-sectional in na ure, carried, sut in school settings and rural areas resper vely (ser Table 1).

However, it is worthy of note that nole size determination, sampling method, a intensity of US were not reported by $49.18 \%(30), 44.5,(33)$ and $46.34 \%$ (19) of the studies inclyan in this review (see Table 1).

\section{Prevalence ar. ntensit, of urinary schistosomiasis} Data on the pre nce of US in different endemic settings re presente, in Table 2 below. In Nigeria, the prevales 14 research articles with a tot samp size of 5675 ranged from $2.07 \%-78.43 \%$. hey howed that 2116 school children were infected, g o an overall prevalence rate of $37.29 \%$. Coincidentally, Kese articles represent the six (6) geopolitical zones of Nigeria.

However, six studies from Kenya reported that of the 25, 809 respondents sampled, 11,728 were infected with the infective stage of $S$. haematobium, giving a prevalence rate of $45.44 \%$. The prevalence of US obtained from Kenya-based literatures ranged from 8.90\%-94\%.

Moreover, two Ethiopia-based research articles retrieved showed that of the 100,030 respondents examined, 310 tested positive yor US, resulting in a prevalence rate of $0.31 \%$.

1. Tameroon, out of the 1346 school children interriewe and examined as reported by two articles, 446 e found to be suffering from the menace of US, giving a prevalence rate of $33.14 \%$.

Furthermore, a prevalence of $67.16 \%$ was computed from a total sample size of 539 reported by two papers which showed that 362 school children were infected.

Finally, each research paper obtained from Malawi, Niger, Ghana, Burkina Faso, Yemen, Zimbabwe, Zambia and Angola reported prevalence rates (sample size) of: $14.20 \%$ (1642), 75.40\% (1642), 50\% (100), 8.76\% (3514), $23.80 \%$ (400), 60\% (551), 9.60\% (2040) and 61.80\% (785) respectively.

Table 2 also presents the extracted data on the intensity of US. It is obvious that only 17 research articles (48.57\%) reported the intensity of infection due to the disease in question. Of this figure, 12 (70.59\%) presented mean intensity of infection as Arithmetic Mean while only 5 (29.41\%) presented it as Geometric Mean.

By Arithmetic format of reporting mean intensity, the highest value, 154.7 eggs per $10 \mathrm{ml}$ of urine sample, was reported in a survey carried out in Magba Region, Cameroon while the runner up value, 107.30 eggs per $10 \mathrm{ml}$ of urine sample, was reported from Kano State, Nigeria. The overall highest mean intensity of infection was reported in Fatick Region, Senegal as a Geometric Mean Intensity of 356.1 eggs per $10 \mathrm{ml}$ of urine sample. The same location recorded the second highest mean egg count of 185 eggs per $10 \mathrm{ml}$ of urine sample. 
Table 1 Descriptive statistics (estimates) of the features of the articles included in the systematic review

\begin{tabular}{|c|c|c|c|c|c|c|c|c|}
\hline Variable & Category A & $\begin{array}{l}\text { Category B } \\
\text { (who region) }\end{array}$ & $\begin{array}{l}\text { Number } \\
\text { of articles }\end{array}$ & $\%$ & Variable & $\begin{array}{l}\text { Category B } \\
\text { (who region) }\end{array}$ & $\begin{array}{l}\text { Number } \\
\text { of articles }\end{array}$ & $\%$ \\
\hline \multirow[t]{23}{*}{ Countries } & Nigeria & Africa & 19 & 20.43 & \multirow{4}{*}{$\begin{array}{l}\text { *Sample size } \\
\text { determination }\end{array}$} & Yes & 11 & 18.03 \\
\hline & Cameroon & Africa & 3 & 3.23 & & Not reported & 30 & 49.18 \\
\hline & Cote d'Ivoire & Africa & 1 & 1.08 & & Could not be & & \\
\hline & Mali & Africa & 1 & 1.08 & & ascertained & & \\
\hline & Kenya & Africa & 8 & 8.60 & \multirow[t]{3}{*}{ *Setting } & School & & \\
\hline & Senegal & Africa & 4 & 4.30 & & Community & & \\
\hline & United State of & The Americas & 3 & 3.23 & & Others & & 21.3 \\
\hline & & & & & \multirow{3}{*}{$\begin{array}{l}\text { *Population } \\
\text { area }\end{array}$} & Rural & & 60.66 \\
\hline & South Africa & Africa & 2 & 2.15 & & Peri-urban & 7 & 11.48 \\
\hline & Switzerland & Europe & 22 & 23.66 & & Others & 17 & 27.87 \\
\hline & Netherlands & Europe & 1 & 1.08 & \multirow{11}{*}{$\begin{array}{l}\text { **Mode of } \\
\text { diagnosis }\end{array}$} & Micros & 18 & 43.90 \\
\hline & Swaziland & Africa & 1 & 1.08 & & & 1 & 2.44 \\
\hline & United Kingdom & Europe & 3 & 3.23 & & & & \\
\hline & Yemen & $\begin{array}{l}\text { Eastern } \\
\text { Mediterranean }\end{array}$ & 1 & 1.08 & & & 1 & 2.44 \\
\hline & Malawi & Africa & 1 & 1.08 & & & 21 & 51.22 \\
\hline & Niger & Africa & 1 & 1.08 & & gent strip & & \\
\hline & Ghana & Africa & 1 & 1.08 & & Arithmetic mean only & 5 & 12.19 \\
\hline & Burkina Faso & Africa & 1 & & & Geometric mean only & 3 & 7.32 \\
\hline & Zimbabwe & Africa & 1 & & & WHO categories only & 13 & 31.71 \\
\hline & Zambia & Africa & 1 & & & $\begin{array}{l}\text { Geometric+ WHO } \\
\text { categories }\end{array}$ & 1 & 2.44 \\
\hline & Tanzania & Africa & & & & $\begin{array}{l}\text { Not reported/Not } \\
\text { specified }\end{array}$ & 19 & 46.34 \\
\hline & Ethiopia & Africa & 2 & 2.15 & \multirow{2}{*}{\multicolumn{4}{|c|}{$\begin{array}{l}\text { *Only applicable to research articles; }{ }^{* *} \text { Only applicable to prevalence/ intensity } \\
\text { studies on humans; cSEA, Circulating Soluble Egg Antigen }\end{array}$}} \\
\hline & Others & & 14) & 15.05 & & & & \\
\hline \multirow{4}{*}{$\begin{array}{l}\text { Type of } \\
\text { Article }\end{array}$} & Research & & & 65.59 & \multirow{11}{*}{\multicolumn{4}{|c|}{$\begin{array}{l}\text { As it stands, Kenya has the highest prevalence while } \\
\text { Senegal has the highest mean intensity of infection with } \\
\text { US among SAC. } \\
\text { Of the } 41 \text { research articles included in this review } \\
\text { paper, } 35 \text { reported a total number of } 144,755 \text { partici- } \\
\text { pants with prevalence/intensity records. As far as } S \text {. hae- } \\
\text { matobium egg concentration technique was concerned, } \\
\text { 11, } 18 \text { and } 4 \text { articles recorded centrifugation, filtration, } \\
\text { and sedimentation as means of preparing sample for } \\
\text { viewing under the microscope. However, } 2 \text { articles from } \\
\text { Angola and Zimbabwe did not report technique of egg } \\
\text { concentration. }\end{array}$}} \\
\hline & Review & & 6 & 6.45 & & & & \\
\hline & Technica & & 22 & 23.66 & & & & \\
\hline & & & 4 & 4.30 & & & & \\
\hline \multirow[t]{10}{*}{ *Sample year } & & & 4 & 6.56 & & & & \\
\hline & & & 4 & 6.56 & & & & \\
\hline & & & 44 & 72.13 & & & & \\
\hline & & & 9 & 14.75 & & & & \\
\hline & & & 2 & 3.28 & & & & \\
\hline & & & 19 & 31.15 & & & & \\
\hline & Universal/census & & 4 & 6.56 & & & & \\
\hline & Stratified & & 2 & 3.28 & & & & \\
\hline & Not reported & & 33 & 54.09 & \multirow{2}{*}{\multicolumn{4}{|c|}{$\begin{array}{l}\text { Risk factors of urinary schistosomiasis in school } \\
\text { children }\end{array}$}} \\
\hline & Fish bowl/ systematic & & 1 & 1.64 & & & & \\
\hline \multirow[t]{3}{*}{ *Study type } & Cross-sectional & & 40 & 65.58 & \multirow{3}{*}{\multicolumn{4}{|c|}{$\begin{array}{l}\text { Table } 3 \text { presents the factors that are considered } \\
\text { pertinent to the transmission of US in school children. } \\
\text { Findings from this review reveal that SAC within the } \\
\text { range of } 5-16 \text { years of age were consistently and } \\
\text { unanimously reported as the group with the highest } \\
\text { prevalence and association with US. }\end{array}$}} \\
\hline & Longitudinal & & 5 & 8.19 & & & & \\
\hline & Not reported & & 16 & 26.23 & & & & \\
\hline
\end{tabular}

Table 1 Descriptive statistics (estimates) of the features of the articles included in the systematic review (Continued)

${ }^{*}$ Only applicable to research articles; ${ }^{* *}$ Only applicable to prevalence/ intensity As it stands, Kenya has the highest prevalence while Senegal has the highest mean intensity of infection with among SAC.

Of the 41 research articles included in this review paper, 35 reported a total number of 144,755 partici11,18 and 4 articles recorded centrifugation, filtration, Angola and Zimbabwe did not report technique of egg

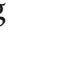


Table 2 Urine Processing Technique, Prevalence, and intensity of urinary schistosomiasis by country's subarea

\begin{tabular}{|c|c|c|c|c|c|c|c|}
\hline Ref & Country & Subarea & $\begin{array}{l}\text { Eggs concentration } \\
\text { technique }\end{array}$ & Sample size & Prevalence (\%) & Mean Intensity & Age group (Years) \\
\hline [45] & Nigeria & Kwara State & Centrifugation & 551 & 35.20 & N.R & $9-16$ \\
\hline [46] & Cameroon & Northern Province & Sedimentation & 964 & 36 & N.R & $9-17$ \\
\hline [47] & Nigeria & Plateau State & Sedimentation & 242 & 2.07 & $27.8^{* *}$ & \\
\hline [48] & Nigeria & Kano State & Centrifugation & 493 & 44.20 & $107.30^{* *}$ & \\
\hline [49] & Kenya & Migori County & Filtration & 1768 & 8.90 & N.R & \\
\hline [50] & Nigeria & Adamawa State & Centrifugation & 232 & 47.80 & $8.30^{* *}$ & \\
\hline [51] & Kenya & Coast Province & Filtration & 12,541 & 41.50 & $45^{*}$ & \\
\hline [52] & Kenya & Coast Province & Filtration & 7093 & 66 & $20^{* *}$ & \\
\hline [53] & Senegal & Fatick Region & Filtration & 329 & 73.20 & & $5-$ \\
\hline [54] & Nigeria & Katsina State & Centrifugation & 611 & 21.11 & & $10-15$ \\
\hline [55] & Kenya & North Coast & Filtration & 262 & 94 & & $5-12$ \\
\hline [56] & Nigeria & Ogun State & Centrifugation & 487 & 57.1 & & $6-14$ \\
\hline [57] & Malawi & Chikhwawa district & Centrifugation & 1642 & & D.R & N.R \\
\hline [58] & Niger & Tillabery /Tahoua & Filtration & 1642 & & $15.50^{*}$ & $7,8 \& 11$ \\
\hline [59] & Kenya & Coast Province & Filtration & 4031 & 35 & N.R & N.R \\
\hline [60] & Ghana & Brong Ahafo Region & Centrifugation & 100 & & N.R & $6-15$ \\
\hline [61] & Senegal & Fatick Region & Filtration & 682 & T. & N.R & $5-15$ \\
\hline [62] & Cameroon & Magba Region & Filtration & & 41.10 & $154.7^{* *}$ & $7-14$ \\
\hline [63] & Senegal & Fatick Region & Filtration & & 57.6 & $185^{*}$ & $7-15$ \\
\hline [64] & Nigeria & Lagos State & Sed & & 78.43 & N.R & $5-15$ \\
\hline [65] & Burkina Faso & Ouagadougou & & & 8.76 & $6^{* *}$ & $7-11$ \\
\hline [66] & Zimbabwe & Chikwaka Communal Land & & 551 & 60 & N.R & $9-16$ \\
\hline [67] & Nigeria & Katsina State & & 436 & 27.98 & $35.29^{* *}$ & $12-17$ \\
\hline [68] & Zambia & Lusaka Province & & 2040 & 9.60 & $31.40^{* *}$ & $6-15$ \\
\hline [69] & Nigeria & Ogun State & Cen/rifugation & 187 & 64.7 & $0.95^{*}$ & $5-15$ \\
\hline [70] & Kenya & Coast Province & fation & 114 & 22.8 & N.R & N.R \\
\hline [71] & Angola & Cubal District & N.R & 785 & 61.80 & N.R & $9-10$ \\
\hline [72] & Yemen & Taiz, lbb__hama & Filtration & 400 & 23.80 & $N \cdot R$ & $\dagger$ \\
\hline [73] & Nigeria & & Centrifugation & 505 & 12.30 & $2.69^{* *}$ & $4-15$ \\
\hline [74] & Nigeria & & Sedimentation & 130 & 23.10 & N.R & $5-16$ \\
\hline [75] & Fthin & a Regional State & Filtration & 304 & 35.90 & $8.76^{* *}$ & $7-14$ \\
\hline [76] & & Alj ost all regions & Filtration & 99,726 & 0.20 & N.R & $10-15$ \\
\hline [77] & & Adamawa State & Centrifugation & 346 & 32.40 & N.R & $5-15$ \\
\hline & & Taraba State & Filtration & 1153 & 53.08 & N.R & $6-15$ \\
\hline & & Cross River State & Filtration & 200 & 21 & $N \cdot R$ & $5-15$ \\
\hline & & & & 144,755 & & & \\
\hline
\end{tabular}

${ }^{*}$ Geometric Mean Intensity; N. R, Not reported; **Arithmetic Mean Intensity; † Not clearly defined

By the findings in this review paper, gender played a significant role in the transmission of US, with males recording higher prevalence of infection and significant association more often over their female counterparts.
Water-related factors like swimming, playing in shallow waters, fetching water for domestic uses in open and potentially infested water bodies like lakes, rivers, ponds, streams, etc. vis a vis proximity of residence to sources of unwholesome water sources have all been reported by 
Table 3 Risk factors of urinary schistosomiasis peculiar to school children

\begin{tabular}{|c|c|c|}
\hline Risk factor & Category & References \\
\hline \multirow[t]{8}{*}{ Age } & 7-9 & {$[62]$} \\
\hline & $5-10$ & [79] \\
\hline & $10-12$ & {$[55]$} \\
\hline & $12-14$ & {$[56]$} \\
\hline & $11-15$ & [53] \\
\hline & $5-15$ & [69] \\
\hline & $6-15$ & [78] \\
\hline & $13-16$ & [74] \\
\hline \multirow[t]{2}{*}{ Gender } & Male & $\begin{array}{l}{[49,53,54,62,63,65,} \\
67,75,78-80]\end{array}$ \\
\hline & Female & {$[64,73,74]$} \\
\hline Recreational activities & $\begin{array}{l}\text { Swimming/play in } \\
\text { shallow water }\end{array}$ & {$[54,73]$} \\
\hline $\begin{array}{l}\text { Water sourcing for } \\
\text { domestic use }\end{array}$ & $\begin{array}{l}\text { *Unwholesome } \\
\text { water sources }\end{array}$ & {$[54,62,67,72,73,81]$} \\
\hline \multirow{5}{*}{$\begin{array}{l}\text { Parental occupation/Farm- } \\
\text { related activities }\end{array}$} & Farming & {$[54,57,73,75]$} \\
\hline & Fishing & {$[54,57,62,67,73]$} \\
\hline & Brown collar jobs & {$[54,67]$} \\
\hline & House wives & {$[54]$} \\
\hline & Irrigation & {$[20]$} \\
\hline $\begin{array}{l}\text { Parental educational } \\
\text { status }\end{array}$ & Illiteracy & {$[72,73]$} \\
\hline \multicolumn{3}{|l|}{$\begin{array}{l}\text { Proximity of residence to } \\
\text { infested water }\end{array}$} \\
\hline Altitude & Valley & \\
\hline $\begin{array}{l}\text { Lack of sewage disposal } \\
\text { facilities }\end{array}$ & Toilet & \\
\hline Changing global climate & & \\
\hline
\end{tabular}

*Rivers, streams, ponds, and dams

researchers as key facion in the transmission of the disease.

In addition, pa-ental tors such as educational and occupational sa save een reported by researchers from various ender settings of US.

Finally economic and ecological factors like lack of sewage nocal facilities and climate change were repor as a rrinant factors of the disease.

\section{Patl. Jgy and morbidity markers of urinary schistosomiasis}

Table 4 presents the pathological consequences and morbidity markers of US by infection phases as reported by the research articles included in this review.

Morbidity markers identified include swimmer's itch, eosinophilia, terminal haematuria, proteinuria, and dysuria. On a broad note, the morbidities/pathological consequences reported obviously revolve around the urogenital
Table 4 Reported morbidities by infection phases of urinary schistosomiasis

\begin{tabular}{|c|c|c|}
\hline Infection Phase & $\begin{array}{l}\text { Morbidity/Pathological } \\
\text { Consequences }\end{array}$ & References \\
\hline Larval Invasion & Swimmers itch & [54] \\
\hline $\begin{array}{l}\text { Acute } \\
\text { (Maturation) }\end{array}$ & Eosinophilia & {$[55]$} \\
\hline \multirow[t]{14}{*}{$\begin{array}{l}\text { Chronic } \\
\text { (Establishment) }\end{array}$} & Terminal haematuria & \\
\hline & Proteinuria & \\
\hline & Dysuria & \\
\hline & Pseudopolyps & \\
\hline & & {$[52,58]$} \\
\hline & Bladd & [20] \\
\hline & & [52] \\
\hline & & {$[55,58,66]$} \\
\hline & & {$[16,55,58]$} \\
\hline & & [16] \\
\hline & & {$[52,66]$} \\
\hline & & {$[69,82]$} \\
\hline & Genital lesions & [16] \\
\hline & Genital swelling/lump & [69] \\
\hline
\end{tabular}

system as shown in Table 4 below. They are majorly associated with the chronic phase of the disease.

Table 5 presents a list of drugs of intervention for US. It shows $\mathrm{PZQ}$ as having the highest cure rate and Niridazole as the least.

Generally, the global population treated for schistosomiasis increased from 2008 to 2016 with the exception of 2011 and 2013 when a decline was experienced (Fig. 2). The same applied to the number of SAC treated as well as their treatment coverage within the same period. The highest distribution coverage for PZQ was achieved in 2016 (see Fig. 3). However, the SAC requiring chemotherapeutic intervention with PZQ kept increasing till 2014 (see Table 6 and Fig. 2).

\section{Discussion}

\section{Results summary}

In summary, the overall findings in this review showed that: (1) of all WHO Regions, Africa is the most endemic zone for US, with Kenya and Senegal recording the highest prevalence and mean intensity respectively; (2) SAC within the range of 5-16 years contribute most significantly to the transmission cycle of the disease globally; (3) gender is a factor to watch out for, with male often recording the highest prevalence and intensity of infection; (4) contact with open, potentially infested water sources contribute significantly to its transmission; (5) parental factors (occupation and 
Table 5 Mode of administration, dosage and cure rate of selected drugs for adult S. haematobium control

\begin{tabular}{lllll}
\hline Drugs & Mode of administration & Dosage & Cure rate & References \\
\hline Antimonials & Intravenous & $30 \mathrm{mg} / 15 \mathrm{~kg}(12$ injections) & $82 \%$ & $36 \%$ \\
Niridazole & Oral & $100 \mathrm{mg} / \mathrm{kg}$ & $50.8 \%$ & {$[83]$} \\
Metrifonate & & $10 \mathrm{mg} / \mathrm{kg}($ single) & $75 \%-85 \%$ & {$[85]$} \\
Praziquantel & & $40 \mathrm{mg} / \mathrm{kg}($ single) & $86]$ \\
\hline
\end{tabular}

education status) predispose SAC to US; (6) economic vis a vis ecological factors play a key role in infection transmission; and (7) in the last decade, a treatment coverage of $45 \%$ was never achieved globally for SAC or non-SAC treatment category for US.

\section{The need to treat school-age children (SAC)}

Meanwhile, schistosomiasis, an infectious disease of poverty, is easily contracted through poor hygiene and play habits of school children. In majority of areas endemic for US, a peak of morbidity is usually observed in school children within age range 7-14 years [16]. On the long run, it prolongs squalor and as a result, blocks cognitive academic performance and normal growth of children. This culminates in suffering and sometimes, death [17]. The extent of morbidity due to US is strongly linked with the intensity and the length of infection period. Because US is more prevalent in SAC, corstrol programme is directed at them so that the do tio of heavy infection intensity could be reduced ma edly $[18,19]$.

Unfortunately, as our findings revealea, ma, ity of SAC are from Africa which had previr usly been re, orted to have accounted for an estimate $f$ over $35 \%$ of all cases of schistosomiasis globally [2 The efore, promoting the health of SAC has nen an integral part of the programme of WHO, United, Aons Educational,
Scientific and Cultural Organization (UNESCO), - d Nations Children's Fund (UNICEF), a other international agencies since the 1950s [21. SA re a target group for Mass Drug Admini ration (M,DA) since WHO expert committee on schis somias s met for the first time 64 years ago $[18,22$

This is ascertained by the pi cted budget of about USD 116 million for 09 to 2013 global procurement and deliverv of dra to endemic countries by WHO and the ON systems without custom fees and clearance chare existing agreements [23, 24]. In Central Nigen study on the epidemiology of US in $\mathrm{SAC} u$ the $\mathrm{W} \mathrm{HO}$ paradigm of $\geq 50 \%$ prevalence has been is a as a benchmark for the treatment of the disease in, adults [25].

\section{Mana ement strategies of urinary schistosomiasis in SAC} a. associated challenges

Various strategies have been applied in the control of US. These include indiscriminate mass treatment, active case finding and treatment of particular risk groups such as school-aged children [26]. However, before the advent of $\mathrm{PZQ}$, other drugs effective against different species and stages of development were used (see Table 5). Drugs of intervention for schistosomiasis progressed from antimonial compounds to PZQ which is the drug of choice today [27]. Metrifonate and Hycathone

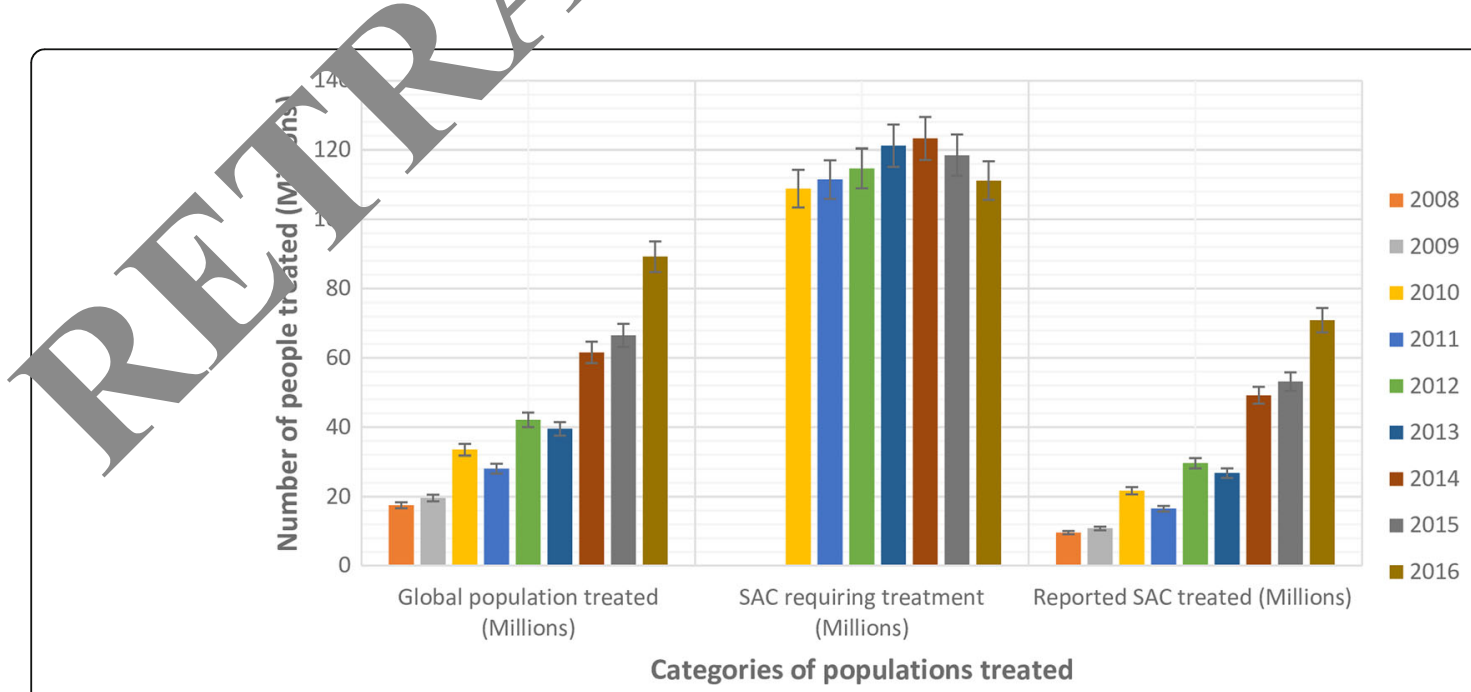

Fig. 2 A clustered column chart showing the population categories of School-Age Children (SAC) treated with Praziquantel between 2008 and 2016 intervention period 


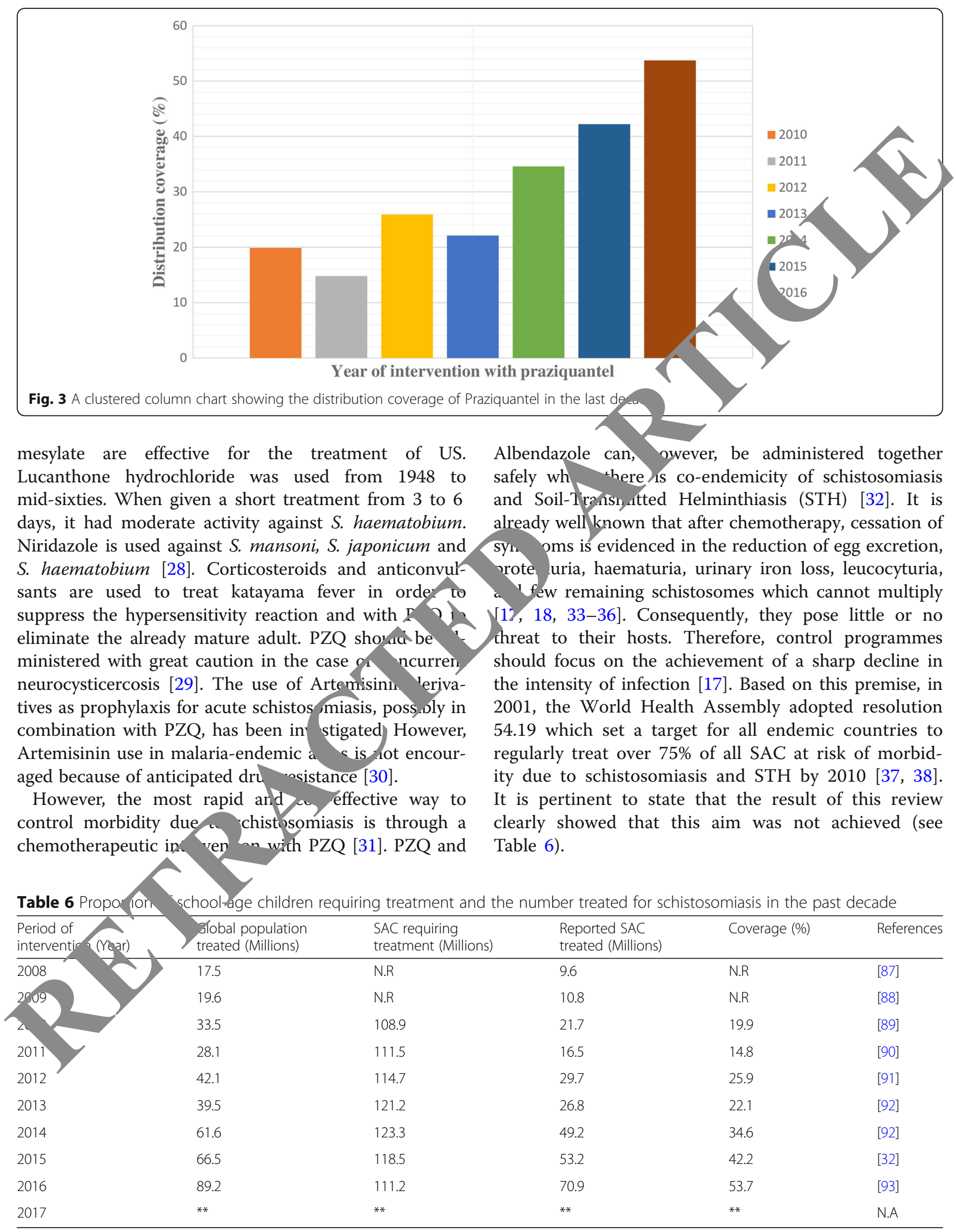

**Data not available yet; SAC School-age Children, NR Not reported, NA Not applicable 
Nevertheless, the greatest challenge of MDA is to extend regular drug coverage to reach all the children at risk of morbidity due to infection by helminths [23]. There are two perspectives to this. One, each School-age Child (SAC) treated may not have access to enough PZQ that would clear all the parasites. Two, the distribution coverage may not cater for the whole population of infected SAC. Consequently, symptoms of chronic infection may show up after 5-15 years in children who were partially treated as a result of poor coverage of PZQ [20]. However, the report of a School-Based Treatment carried out in Zanzibar Island, Tanzania, where 8000 pupils were treated showed amazing coverage of 85.2 and $86.9 \%$ in Pemba and Unguja Districts respectively [39].

PZQ is not without its adverse reactions like abdominal pain, dizziness, headache, vomiting, diarrhea, round, swollen and itching skin rashes, and fever [40]. These are usually mild and last for $24 \mathrm{~h}$. These are reactions from dying worms.

In addition, studies have shown that false negative results cause infected SAC to escape treatment, leading to chronic condition and if such case occurs after MDA, cure rate may be overestimated and this may be a prelude to drug resistance and further transmission of US [41].

It is hoped that in the nearest future, global somiasis control programmes will receive a bost the current "evolutionary" process of ya ne-linke, chemotherapy culminates in approval by W $\mathrm{HO}$. good number of these vaccines undergoi ig preclinic, and clinical trials on the field are pa icularly made for children [42].

\section{Limitations of the review}

This review took articleo orted in English into consideration instead of $\mathcal{A}$ ud those reported in other languages. Besides, we ticed that mean intensity of infection witb was ther underreported or not reported by some thors of articles included in this review a cicle. Conses ${ }_{1}$ uently, the report of the mean intensity of $t$ is aisable among SAC globally.

\section{c. clusion}

The Evalence rates and intensities of US vis a vis its impact on SAC, keep increasing from year to year, leading to increase in the global population requiring chemotherapeutic intervention with PZQ. In view of the WHO strategic ambitious plan to eliminate schistosomiasis by 2020 [43] and the findings from this review stipulating that in the last decade, a PZQ distribution coverage of $45 \%$ has never been achieved for SAC, it is obvious that this goal, in the face of realities, might not be achieved just like the strategic plan for 2010. Our view is in agreement with the report that if WHO sustains the current treatment trend, elimination is achievable in 2030 [44]. It is imperative that annual control programmes be scaled up marginally, particularly in the African region of the WHO. While US-based rese rches should be sponsored at the grass-root level onveil hidden endemic foci, adequate facilities for ater Sanitation, and Hygiene (WASH) should be put in ce in all schools globally.

\section{Acknowledgements}

We express our profound gratitude to the aut ors of the research papers, review articles and online materials used in th surse of preparing the manuscript of this review article. Witbo heir as contribution to knowledge about schistosomiasis, top pap written with scanty references.

Funding

Not applicable.

Availability of data

Not applicable.

Authors' con

TEA conceived th rey ew. TEA and TOA searched for relevant literatures and wrote the manu script. Both authors read and approved the final version of

thics proval and consent to participate

apricable.

Consent for publication

vot applicable.

Competing interests

The authors declare that they have no competing interests.

\section{Publisher's Note}

Springer Nature remains neutral with regard to jurisdictional claims in published maps and institutional affiliations.

\section{Author details}

${ }^{1}$ Department of Biological Sciences, Federal University, Dutsin-Ma, Km 65, P.M.B. 5001, Dutsin-Ma, Katsina State, Nigeria. ${ }^{2}$ Department of Biological Sciences and Biotechnology, College of Pure and Applied Sciences, Caleb University, Imota, Lagos State, Nigeria.

Received: 8 January 2018 Accepted: 21 December 2018

Published online: 18 January 2019

References

1. Colley DG, Bustinduy AL, Secor WE, King CH. Human schistosomiasis. Lancet. 2014;383(9936):2253-64.

2. World Health Organization. Schistosomiasis. Fact sheet 115 updated January 2017. Available at: http://www.who.int/mediacentre/factsheets/fs115/en/. Accessed on 8 June 2017.

3. Steinman P, Keiser J, Bos R, Tanner M, Utzinger J. Schistosomiasis and water resources development: systematic review, meta-analysis and estimates of people at risk. Lancet Infect Dis. 2006;6:411-25.

4. Atalabi TE, Lawal U, Ipinlaye SJ. Prevalence and intensity of genito-urinary schistosomiasis and associated risk factors among junior high school students in two local government areas around Zobe Dam in Katsina state, Nigeria. Parasit Vectors 2016a; 9:388.

5. Atalabi TE, Lawal U, Akinluyi FO. Urogenital schistosomiasis and associated determinant factors among senior high school students in the Dutsin-ma and Safana local government areas of Katsina state, Nigeria. Infect Dis Poverty 2016b; 5:69. 
6. World Health Organization. Schistosomiasis: Epidemiological situation. Updated January 2017. Available at: http://www.who.int/schistosomiasis/ epidemiology/en/. Accessed on 8 June 2017.

7. Feldmeier H. Female genital schistosomiasis as a risk-factor for the transmission of HIV. Int J STD AIDS. 1994;5(5):368-72.

8. King $\mathrm{CH}$, Dickman $\mathrm{K}$, Tisch DJ. Reassessment of the cost of chronic helmintic infection: a meta-analysis of disability-related outcomes in endemic schistosomiasis. Lancet. 2005;365(9470):1561-9.

9. Stothard JR, Sousa-Fifueiredo JC, Bethson M, Bustinduy A, Reinhard-Rupp J. Schistosomiasis in African infants and preschool children: let them now be treated! Trends Parasitol. 2013;29(4):197-205.

10. Koukounari A, Gabrielli AF, Touré S, Bosqué-Oliva E, Zhang Y, Sellin B, Donnelly CA, Fenwick A, Webster JP. Schistosoma haematobium infection and morbidity before and after large-scale administration of Praziquantel in Burkina Faso. J Infect Dis. 2007;196(5):659-69.

11. Umerah BC. Bilharzial hydronephrosis: a clinic-radiological study. J Urol. 1981;126(2):164-5

12. Savioli L, Gabrielli AF, Montresor A, Chitsulo L, Engels D. Schistosomiasis control in Africa: 8 years after world health assembly resolution 54.19. Parasitology. 2009;136(13):1677-81.

13. World Health Organization. Preventive chemotherapy in human helminthiasis: coordinated use of anthelminthic drugs in contro interventions. Geneva: World Health Organization; 2006a. Available at: http://apps.who.int/iris/bitstream/10665/43545/1/9241547103_eng.pdf. Accessed on 8 June 2017 b.

14. Woolhouse MEJ. Patterns in parasite epidemiology: the peak shift. Parasitol Today. 1998;14:428-34

15. World Health Organization. Prevention and control of schistosomiasis and soil-transmitted helminthiasis. Report of a WHO expert committee. Geneva: WHO; 2002a (WHO Technical Report Series No. 912). pp. 1-57.

16. WHO Expert committee on ultrasound in schistosomiasis: a practical guide to the standardized use of ultrasonography for the assessment of schistosomiasis, related morbidity. Second international workshop. Richter J, Hatz C, Campaøne G, Bergquist NR, Jenkins JM (editors). Niamey, Niger; October 22-26, 1996. World Health Organization (TDR/STR/SCH/00.1.), 2000; 49pp.

17. World Health Organization. Helminth control in school-age children: for managers of control programmes. Montresor A, Crompto DWT, Gyorkos TW, Savioli L (editors). World Health Organization a

18. WHO Expert committee on the control of schiostosomiasis: su fond Geneva, World Health Organization, 1993 (WHO Technical Repe senes, No. 830,

19. World Health Organization. How to deworm sch ol-age children: ) instructions for teachers. Montresor A (editor); K i-ka- Batembo (designer and illustrator). World Health Organization (WHC S/ CPE, VC/ 2003.6/ Rev1); 2004, 20pp.

20. World Health Organization. The social $d$ schistosomiasis and its control: an introduction and annotated biblifgra, y. UNICEF/UNDP/World Bank/WHO Special Programr Researc and Training in Tropical Diseases. Birgitte Bruun ar Jens agaard-t Ansen (Editors). World Health Organization 2008, 2

21. World Health Orgar, «ation. P, the health through schools: Report of a WHO Expert cor, ee on com, -nensive school health education and promotion. W rld A Organization, 1997 (WHO Technical Report Series, No. 870); $\mathrm{sp}$.

22. WHO F pert committee on Bilharziasis: first report. Geneva, World Health Organ on 953 'WHO Technical Report Series, No. 65)

23. World Hu Orga ization. Monitoring drug coverage for preventive nothera Norld Health Organization 2010b (WHO/HTM/NTD/PCT/ 1) iothera

24. IOnu multh Organization. Informal consultation on expanding tosomiasis control in Africa. World Health Organization 2010c, 38pp.

25. Evo, 1s DS, King JD, Eigege A, Umaru J, Adamani W, Alphonsus K, Sambo Y, Miri ES, Goshit D, Ogah G, Richards FO. Assessing the WHO 50\% prevalence threshold in school-aged children as indicator for the treatment of urinary schistosomiasis in adults in Central Nigeria. Am J Trop Med Hyg. 2013;88(3):441-5.

26. Cioli D, Botros SS, Wheatcroft-Francklow K, Mbaye A, Southgate $V$, TLA T, Pica-Mattoccia L, Troiani AR, Seif El-Din SH, ANA S, Albin J, Engels D, Doenhoff MJ. Determination of ED50 Values for Praziquantel in Praziquantel-Resistant and susceptible Schistosoma mansoni isolates. Int. J. Parasitol. 2003;34:979-87.

27. El Ridi RAF, Tallima HA-M. Novel therapeutic and prevention approaches for schistosomiasis. Review J Adv Res. 2013;4:467-78.
28. Shekhar KC. Schistosomiasis drug therapy and treatment considerations. Drugs. 1991;42(3):379-405.

29. Fong GCY, Cheung RTF. Caution with praziquantel in neurocysticercosis. Stroke. 1997;28:1648-9.

30. Utzinger J, Keiser J, Shuhua X, Tanner M, Singer BH. Combination chemotherapy of schistosomiasis in laboratory studies and clinical trials. Antimic Agents chem. 2003;47:1487-95.

31. World Health Organization. Schistosomiasis: Progress report 2001-201 and strategic plan 2012-2020. Preventive Chemotherapy and Tran Control (PCI), Department of Control of Neglected Tropical Dise HTM/NTD/PCT/2013.2), 74pp.

32. World Health Organization. Schistosomiasis and so helminthiases: number of people treated in 2015. W/kly t niol rec 2016b; 91(49/50): 585-600.

33. Keiser J, Silué KD, Adiossan LK, N'Guessan I Monsan N Utzinger J, N'Goran EK. Praziquantel, Mefloquinip -PZQ Meflocainine-ArtesunatePZQ against Schistosoma haematoor rano a, exploratory, openlabel trial. PLoS Negl Trop Dis. 2014:8(7). 75

34. Sissoko MS, Dabo A, Traoré Diallo M, Trà B, Konaté D, Niaré B, Diakité $M$, Kamaté $B$, Traoré $A, B$ hily vpily $A$, Touré $O B$, Cauwenbergh $S$, Jansen HF, Doumbo OK. Efficacy tesunate + Sulfamethoxypyrazine/ Pyrimethamine ver sus ziquantel the treatment of Schistosoma haematobium i bildre LPLS One. 2009;4(10):e6732.

35. Inyang-Etoh PC, $\mathrm{B}, \mathrm{MF}$, Inyang-Etoh EC. Efficacy of artesunate in the treatment of ry schistosomiasis, in an endemic community in Nigeria. Trop Med arasitol. 2004;98(5):491-9.

36. Ezeagwul a D. rdu IM, Onyido AE, Nnamah NK, Oli AN, Mgbemena IC, Ogolo BC, $1 \mathrm{~N}$. E-ticacy of artesunate in the treatment of urinary schistosomi sis in an endemic area in Anambra state, Nigeria. Int Res J yrm Pharmacol. 2012;2(1):034-9.

37. Expert committee on the control of schiostosomiasis: first report. Ge eva, World Health Organization, 1985 (WHO Technical Report Series, No. 3); $113 \mathrm{pp}$.

38. World Health Organization. Schistosomiasis and Soil-Transmitted Helminth infections-Preliminary estimates of the number of children treated with albendazole or mebendazole. Wkly Epidemiol. Rec. 2006b; 81 (16): 145-164.

39. Knopp S, Person B, Ame SM, Ali SM, Muhsin J, Juma S, Khamis IS, Rabone M, Blair L, Fenwick A, Mohammed KA, Rolinson D. Praziquantel coverage in schools and communities targeted for the elimination of urogenital schistosomiasis in Zanzibar: a cross-sectional survey. Parasit Vectors. 2016;9:5

40. Ahmed SH. Schistosomiasis (Bilharzia) treatment and management. In: Drugs and Diseases- Infectious Diseases. 2017. Medscape. Available at: http:// emedicine.medscape.com/article/228392-treatment. Accessed on 13 July 2017.

41. Ochodo EA, Gopalakrishna G, Spek B, Reitsma JB, van Lieshout L, Polman K, Lamberton P., Bossuyt PMM, Leeflang MMG. Circulating antigen tests and urine reagent strip for diagnosis of active schistosomiasis in endemic areas. Cochrane Database of Systematic Reviews 2015; Issue 3, Art. No.: CD009579.

42. Marrifield M, Hotez PJ, Beaumier CM, Gillespie P, Strych U, Hayward T, Bottazzi ME. Advancing a vaccine to prevent human schistosomiasis. Vaccine. 2016;34:2988-91.

43. Utzinger J, Becker SL, van Lieshout L, van Dam GJ, Knopp S. New diagnostic tools in schistosomiasis. Clin Microbiol Infect. 2015;21(6):529-42.

44. Anderson RM, Turner HC, Farrell SH, Yang J, Truscott JE. What is required in terms of mass drug administration to interrupt the transmission of schistosome parasites in regions of endemic infection? Parasit Vectors. 2015;8:553.

45. Adedoja AA, Akanbi AA, Oshodi AJ. Effect of Artemether-lumefantrine treatment of falciparum malaria on urinary schistosomiasis in co-infected school aged children in north central of Nigeria. Int J Biol Chem Sci. 2015:9(1):134-40.

46. Takougang I, Meli J, Fotso S, Angwafo F III, Kamajeu R, Ndumbe PM. Haematuria and dysuria in the self-diagnosis of urinary schistosomiasis among school-children in northern Cameroon. Afr J Health Sci. 2004;11:121-7.

47. Dawet A, Yakubu DP, Longmut R, Benjamin CB, Daburum YH, Nannim N. Prevalence and intensity of Schistosoma haematobium among residents of Gwong and Kabong in Jos north local government area, plateau state, Nigeria. Int J Biol Chem Sci. 2012;6(4):1557-65.

48. Duwa MR, Oyeyi TI, Bassey SE. Prevalence and intensity of urinary schistosomiasis among primary school pupils in Minjibir local government area of Kano state, Bayero. J Pure Appl Sci. 2009;2(1):75-8.

49. Ng'ang'a M, Matendechero S, Kariuki L, Omondi W, Makworo N, Owiti PO, Kizito W, Tweya H, Edwards JK, Takarinda KC. Omondi-Ogutu. Spatial 
distribution and co-infection with urogenital and intestinal schistosomiasis among primary school children in Migori County, Kenya. East Afr. Med J. 2016;93(10):S22-31.

50. Birma JS, Chessed G, Shadrach PA, Nganjiwa JI, Yako AB, Vandi P, Laurat TJ. Urinary schistosomiasis in communities around Kiri Lake, Shelleng local government area, Adamawa state, Nigeria. Appl Sci Environ Manag. 2017; 21(1):128-34.

51. Magnussen $P$, Muchiri E, Mungai $P$, Ndzovu M, Ouma J, Tosha S. A schoolbased approach to the control of urinary schistosomiasis and intestinal helminth infections in children in Matuga, Kenya: impact of a two-year chemotherapy programme on prevalence and intensity of infections. Tropical Med Int Health. 1997;2(9):825-31.

52. King $\mathrm{CH}$, Muchiri EM, Ouma JH. Age-targeted chemotherapy for control of urinary schistosomiasis in endemic populations. Mem Inst Oswaldo Cruz. 1992;87(4):203-10.

53. Senghor B, Diaw OT, Doucoure S, Sylla SN, Seye M, Talla I, Ba CT, Diallo A, Sokhna C. Efficacy of Praziquantel against urinary schistosomiasis and reinfection in Senegalese school children where there is a single well defined transmission period. Parasit Vectors. 2015;8:362.

54. Atalabi TE, Adubi TO, Lawal U. Rapid mapping of urinary schistosomiasis: an appraisal of the diagnostic efficacy of some questionnaire-based indices among high school students in Katsina state, Northwestern Nigeria. PLoS Negl Trop Dis. 2017;11(4):e0005518.

55. Njaanake KH, Vennervald BJ, Simonsen PE, Madsen $H$, Mukoko DA, Kimani G, Jaoko WG, Benson B. Schistosoma haematobium and soiltransmitted helminths in Tana Delta district of Kenya: infection and morbidity patterns in primary schoolchildren from two isolated villages. BMC Infec Dis. 2016;16:57

56. Morenikeji O, Quazim J, Omoregie C, Hassan A, Nwuba R, Anumudu C, Adejuwon S, Salawu O, Jegede A, Odaibo A. A cross-sectional study on urinary schistosomiasis in children; haematuria and proteinuria as diagnostic indicators in an endemic rural area of Nigeria. Afr Health Sci 2014;14(2):390-6.

57. Chipeta MG, Ngwira B, Kazembe LN. Analysis of schistosomiasis haematobium infection prevalence and intensity in Chikhwawa, application of a two part model. PLoS Negl Trop Dis. 2013;7(3): 213

58. Tohon ZB, Mainassara HB, Garba A, Mahamane AE, Bosque-C'va E, Ibrar M-L, Duchemin J-B, Chanteau S, Boisier P. Controlling Sch's niasis. Significant Decrease of Anaemia Prevalence One Year an er a S, Dose of Praziquantel in Nigerien Schoolchildren. PLoS Negl inopDis. 2008, <241.

59. King $\mathrm{CH}$, Muchiri EM, Ouma JH. Evidence agains rapid emergence of Praziquantel resistance in Schistosoma haemato m, Kenya. Imerging Infect Dis. 2000;6(6):585-94

60. Afrifa J, Gyedu D, Gyamerah EO, Essiem Raidoo S, Mu_rssilfie I. Haematological Profile and Intensity of chistosomiasis in Ghanaian Children. J. Environ. Pub. Health. 2017;Art cle ou 3325:5.

61. Senghor B, Diaw OT, Doucor Seye M, Siallo A, Talla I, Bâ CT, Sokhna C. Impact of annual Praziqu tel tre ment or arogenital schistosomiasis in a seasonal transmission foca. Plegal. PLoS Negl Trop Dis. 2016; 10(3):e0004557.

62. Njunda AL, Ndzi Mssob JCN, Mga H-LF, Kwenti ET. Prevalence and factors associa ed $\mathrm{m}$. rinary schistosomiasis among primary school children in arrage, mà cab-division of Cameroon. BMC Public Health. 2017:17618

63. Sengr No A Sylla SN, Doucoure S, Mo N, Gaayeb L, DjuikwoTeukeng Bâ CT Sokhna C. Prevalence and intensity of urinary tosomia among school children in the district of Niakhar, region of Fat k Senegal. Parasit Vectors. 2014;7:5

OA, Fagbemi OB. Prevalence and risk factors of Schistosoma matobium infections among primary school children in Igbokuta Village Iko odu north local government, Lagos state. IOSR J Nur Health Sci. 2013; 2(6):62-8.

65. Ouedraogo H, Drabo F, Zongo D, Bagayan M, Bamba I, Pima T, YagoWienne F, Toubalie E, Zhang Y. Schistosomiasis in school-age children in Burkina Faso after a decade of preventive chemotherapy. Bull World Health Organ. 2016;94:37-45.

66. Brouwer KC, Munatsi A, Ndhlovu PD, Wagatsuma Y, Shiff CJ. Urinary schistosomiasis in Zimbabwean school children: predictors of morbidity. Afr Health Sci. 2004;4(2):115-8.

67. Atalabi TE, Lawal U, Akinluyi FO. Urinary schistosomiasis and associated determinant factors among senior high school students in the Dutsin-ma and Safana local government areas of Katsina state, Nigeria. Infect Dis Poverty 2016b; 5:69.

68. Simoonga C, Kazembe LN. Using the hierarchical ordinal regression model to analyse the intensity of urinary schistosomiasis infection in school children in Lusaka Province, Zambia. Infec Dis Poverty. 2017;6:43.

69. Ekpo UF, Odeyemi OM, Sam-Wobo SO, Onunkwor OB, Mogaji HO, Oluwole AS, Abdussalam HO, Stothard JR. Female genital schistosomiasis (FGS) in Ogun state, Nigeria: a pilot survey on genital symptoms and clinic ar findings. Parasitol Open. 2017;3(e10):1-9.

70. Vinkeles Melchers NVS, van Dam GJ, Shaproski D, Kahama Al, Bis Vennervald BJ, van Lieshout L. Diagnostic performance of Schistoso Rea time PCR in urine samples from Kenyan children infe ed with Schistos ma haematobium: day-to-day variation and follow-up afto vziquante treatment. PLoS Negl Trop Dis. 2014;8(4):e2807/ms://a $/ / 10 / 371 /$ journal.pntd.0002807.

71. Bocanegra C, Gallego S, Mendioroz J, More M, Sulleiro E, Salvador F, Sikaleta N, Nindia A, Tchipita D, Joror ba M , raya S, Nontalvá AS, López T, Molina I. Epidemiology of schistosor ana ress of indirect diagnostic tests in school-age surdren Trop Dis. 2015;9(10):e00040

72. Sady H, Al-Mekhlafi HM, ahà, MK, Lim YAL, Mahmud R, Surin J. Prevalence and associated factors chistosomiasis among children in Yemen: implication n effective, ontrol Programme. PLoS Negl Trop Dis. 2013;7(8):

73. Bishop $\mathrm{HG}$, Inabo valence and intensity of urinary schistosomiasis and effects on packed cell volume of pupils in Jaba LGA, Nid Edorium, vicrobiol. 2016;2:13-26.

74. Goodhea 'Dr. Prevalence of urinary schistosomiasis among pupils in el emic communities of Rivers state, Nigeria. Am J Microbiol Biotechnol. 016;3(2):7-12

leta S, Alemu A, Getie S, Mekonnen C, Erko B. Prevalence of urinary tosomiasis and associated risk factors among Abobo primary school chi ren in Gambella regional state, southwestern Ethiopia: a cross-sectional str, dy. Parasit Vectors. 2015;8:215.

76. Grimes JET, Tadesse G, Mekete K, Wuletaw Y, Gebretsadik A, French MD, Harrison WE, Drake LJ, Gardiner IA, Yard E, Templeton MR. School water, sanitation, and hygiene, soil-transmitted helminths, and Schistosomes: national Mappingin Ethiopia. PLoS Negl Trop Dis. 2016;10(3):e0004515. https://doi.org/10.1371/journal.pntd.0004515.

77. Balla HJ, Jabbo AA. Survey of urinary schistosomiasis among school-aged children in the rural communities of Mayo-belwa local government area, Adamawa state, Nigeria. J Nat Sci Res. 2013;3(4):73-7.

78. Houmsou RS, Agere H, Wama BE, Bingbeng JB, Amuta EU, Kela SL. Urinary Schistosomiasis among Children in Murbai and Surbai Communities of Ardo-Kola Local Government Area, Taraba State, Nigeria. J. Trop. Med. 2016; Article ID 9831265:7.

79. Inyang-Etoh PC, Daniel AE, Ofonime MO, Opara-Osuoha U. Urinary schistosomiasis and intestinal parasitosis coinfection among school age children in Adim community, Nigeria. Int J Sci. 2017;6:10-5.

80. Frigerio S, Bert F, Clari M, Fine GD, Riva S, Bergese I, Diouf SG, Alvaro R, Buonomo E. Knowledge, attitudes and practices related to schistosomiasis in northern Senegal. Annals of Global Health. 2016;82(5):841-7.

81. Adenowo AF, Oyinloye BE, Ogunyinka BI, Kappo AP. Impact of human schistosomiasis in sub-Saharan Africa. Braz J Infect Dis. 2015;19(2):196-205.

82. World Health Organization. Female Genital Schistosomiasis: A Pocket Atlas for Clinical Health-Care Professionals. World Health Organization (WHO/ HTM/NTD/2015.4), 49pp.

83. Farid Z, Bassily S, Kent DC, Hassan A, Abdel-Wahab MF, Wissa J. Urinary schistosomiasis treated with sodium antimony tartrate-a quantitative evaluation. Br Med J. 1968:3(5620):713-4.

84. Ejima IAA. Comparative evaluation of the efficacy of Praziquantel (PZQ) and Niridazole/Ambilhar (N/a) in the treatment of urinary schistosomiasis among school children examined in Idah and Ibaji local government areas (LGAs) of Kogi state, Nigeria. Int J Mol Med Advance Sci. 2015;11:1-8.

85. Tswana SA, Mason PR. Single dose Metrifonate in the treatment of urinary schistosomiasis in an area of low prevalence and intensity of infection. Central Afr J Med. 1986;32(6):133-7.

86. Magaisa K, Taylor M, Kjetland EF, Naidoo PJ. A review of the control of schistosomiasis in South Africa. S Afr J Sci. 2015;111(11/12):1-6.

87. World Health Organization. Schistosomiasis: number of people treated, 2008. Wkly Epidemiol. Rec. 2010a; 85 (18): 157-164. 
88. World Health Organization. Schistosomiasis: number of people treated, 2009. Wkly Epidemiol. Rec. 2011; 86 (9): 73-80.

89. World Health Organization. Schistosomiasis: population requiring preventive chemotherapy and number of people treated in 2010. Wkly Epidemiol. Rec. 2012; 87 (4): 37-44.

90. World Health Organization. Schistosomiasis: number of people treated in 2011. Wkly Epidemiol. Rec. 2013a; 88 (8): 81-88.

91. World Health Organization. Schistosomiasis: number of people receiving preventive chemotherapy in 2012. Wkly Epidemiol. Rec. 2014; 89 (2): 21-28.

92. World Health Organization. Schistosomiasis: number of people treated worldwide in 2014. Wkly Epidemiol. Rec. 2016a; 91 (5): 53-60.

93. World Health Organization. Schistosomiasis and soil-transmitted helminthiases: number of people treated in 2016. Wkly Epidemiol. Rec. 2017; 49(92): 749-760.

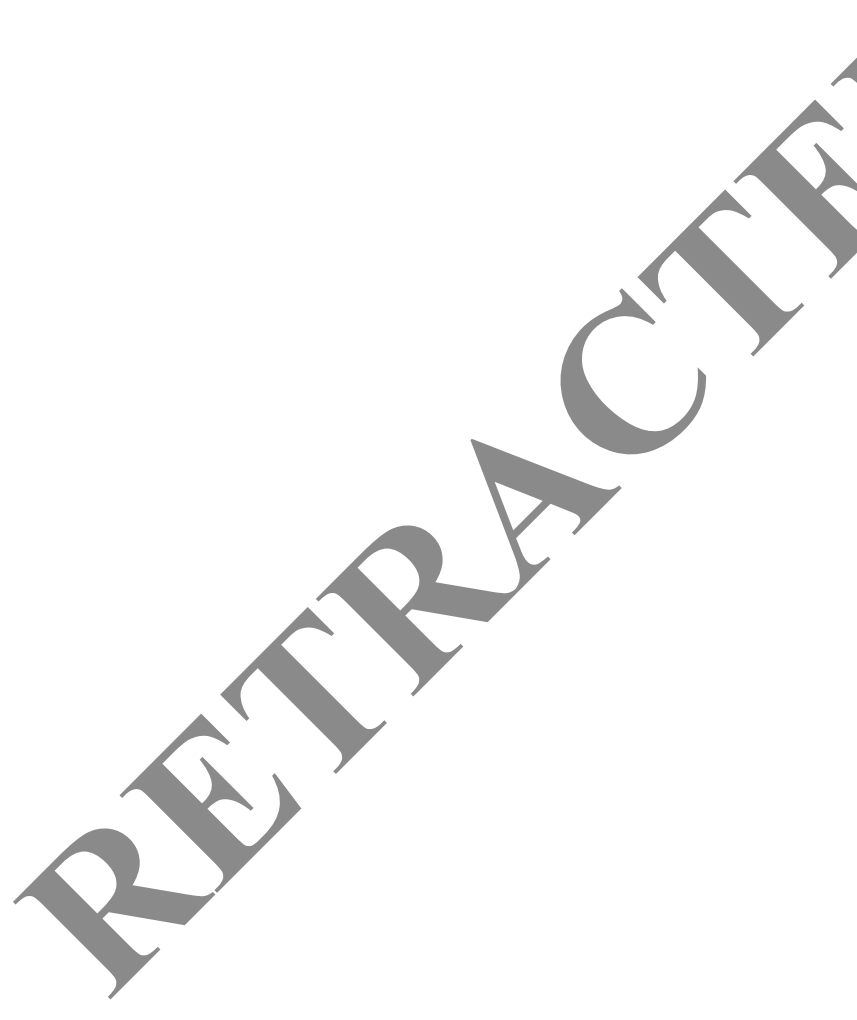

Ready to submit your research? Choose BMC and benefit from:

- fast, convenient online submission

- thorough peer review by experienced researchers in your field

- rapid publication on acceptance

- support for research data, including large and complex data types

- gold Open Access which fosters wider collaboration and increased citations

- maximum visibility for your research: over $100 \mathrm{M}$ website views per year

At BMC, research is always in progress.

Learn more biomedcentral.com/submissions 